In the Company of Scholars 
THIS PAGE INTENTIONALLY LEFT BLANK 


\section{In the Company \\ of Scholars}

The Struggle

for the Soul of

Higher Education

- JULIUS GETMAN •

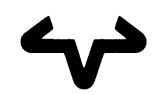

University of Texas Press, Austin 


\section{Copyright $\left({ }_{1} 1992\right.$ by the University of Texas Press \\ All rights reserved \\ Printed in the United States of America \\ First edition, 1992}

Requests for permission to reproduce material from this work should be sent to Permissions, University of Texas Press, Box 78 19, Austin, Tx $78713-7819$.

\section{Library of Congress Cataloging-in-Publication Data}

\section{Getman, Julius G.}

In the company of scholars : the struggle for the soul of higher education / Julius Getman.

p. $\mathrm{cm}$.

Includes bibliographical references.

ISBN 0-292-72755-0

I. Education, Higher-United States-Philosophy. 2. Education, HigherPolitical aspects-United States. 3. Education, Humanistic-United

States. 4. Elites (Social sciences)_United States.

I. Title.

$$
\begin{aligned}
& \text { LA22 27.G4 } 8 \quad 1992 \\
& 378.73 \text {-dc2O }
\end{aligned}
$$

ISBN 978-0-292-73517-0 (library e-book)

ISBN 978-0-292-78650-9 (individual e-book) 
To the memory of my father, Samuel Getman, 1900-1959, and to my mother, Charlotte Getman, from whom I learned that pleasure in ideas, intelligence, curiosity about people, love of music, art, and literature do not require formal education. 
THIS PAGE INTENTIONALLY LEFT BLANK 